\title{
Seed bank and plant community composition, Mixed Prairie of Saskatchewan
}

\author{
J.T. ROMO AND Y. BAI
}

Authors are Professor and Assistant Professor, Dept. of Plant Sciences, Univ. of Saskatchewan, 5I Campus Drive, Saskatoon, Saskatchewan S7N 5A8.

Abstract

Many range managers have suggested that clubmoss (Selaginella densa Rydb.) negatively alters the composition of seed banks and inhibits the establishment of plant species that decrease under improper grazing management. Alternatively it is possible that soil seed banks contain few seeds of decreaser species and composition of the seed bank is independent of clubmoss. The purpose of this study was to determine the composition and diversity of the soil seed bank in relation to the clubmoss cover and compositional characteristics of plant communities in the Northern Mixed Prairie of southwestern Saskatchewan. Cover of vascular plants was determined and soil seed bank samples were collected in 100 grazed plant communities. Soil seed bank samples were incubated in the laboratory with emerging seedlings being identified to species. Eight percent $(\mathrm{SE} \pm 1.9)$ of emerging seedlings in the seed bank were decreasers, $73 \%$ (SE \pm 2.8) were increasers, and $19 \%(\mathrm{SE} \pm 2.3)$ were invaders, indicating regeneration of decreaser species might be limited by low numbers of seeds in seed banks. Clubmoss cover was not correlated $(P=0.32$ to 0.98$)$ with species richness, species diversity, density of decreasers, density of increasers, density of invaders, and total seedling densities in the seed banks. Seed banks and plant communities shared few species as indicated by a low similarity index $(\overline{\mathrm{x}}=\mathbf{0 . 3 1}, \mathrm{SE} \pm \mathbf{0 . 0 2})$. Species richness $(\overline{\mathrm{x}}=3.6$ species per $\left.102 \mathrm{~cm}^{2}, \mathrm{SE} \pm 0.18\right)$ and diversity $(\overline{\mathrm{x}}=1.00, \mathrm{SE} \pm 0.05)$ of seed banks were poorly correlated with characteristics of the plant communities. Range condition score was positively correlated ( $r$ $=0.17, P=0.09$ ) with total seedling densities in the soil seed bank, indicating more seedlings can potentially develop from the seed bank with increasing range condition of plant communities. We reject the hypothesis that clubmoss negatively affects the composition of seed banks. Mechanically disturbing plant communities to control clubmoss is predicted to lead to plant communities that are dominated by increasers and/or invaders. Managing for production of seeds by desired species should be a priority in promoting establishment of desired species.

Key Words: biodiversity, microbiotic crust, microphytic crust, Northern Mixed Prairie, range condition, Selaginella densa

Clubmoss (Selaginella densa Rydb.), a low-growing, vascular cryptogam, forms carpet-like mats on a wide range of sites in grasslands of the Northern Great Plains (Coupland 1950, Van

Funding for this research was provided by a research grant to JTR from the Saskatchewan Agriculture Development Fund (Project-9600054).

Manuscript accepted 15 Jul. 03.

\section{Resumen}

Muchos manejadores de pastizles han sugerido que el "Clubmoss" (Selaginella densa Rydb.) altera negativamente la composición de los bancos de semillas e inhibe el establecimento de especies de plantas que decrecen bajo un menejo inadecuado del apacentamiento. Alternativamente es posible que los bancos de semillas del suelo contengan pocas semillas de especies decrecientes y que la composicion del banco de semillas de es independiente del "Clubmoss". El propósito de este estudio fue determinar la composición y diversidad del banco de semillas del suelo en relación a la cobertura de "Clubmoss" y las características de composición de las comunidades vegetales de las Praderas Mixtas del Norte en el Sudoeste de Saskatchewan. Se determinó la cobertura de plantas vasculares y se colectaron muestras del banco de semilla en 100 comunidades de plantas apacentadas. Las muestras del banco de semillas se incubaron en el laboratorio y las plantas emergidas fueron identificadas por especie. $\mathbf{8 \%}$ $(\mathrm{SE} \pm 1.9)$ de las plántulas emergidas del banco de semillas fueron especies decrecientes, $73 \%(\mathrm{SE} \pm 2.8$ ) fueron espeies crecientes y $19 \%(\mathrm{SE} \pm \mathbf{2 . 3})$ fueron invasoras, indicando que la regeneración de especies decrecientes puede ser limitada por el bajo número de semillas en los bancos de semillas. La cobertura de "Clubmoss" no estuvo correlacionada $(P=0.32$ to 0.98$)$ con la riqueza de especies, densidad de especies decrecientes, crecientes e invasoras y las densidades totales de plántulas emergidas en el banco de semillas. Los bancos de semillas y las comunidades de plantas comparten pocas especies tal como lo indica el bajo indice de similaridad $(\bar{x}=0.31, S E \pm 0.02)$. La riqueza de especies $\left(\overline{\mathrm{x}}=3.6\right.$ species per $\left.102 \mathrm{~cm}^{2}, \mathrm{SE} \pm 0.18\right)$ y diversidad $(\overline{\mathrm{x}}=$ $=1.00, \mathrm{SE} \pm 0.05)$ de los bancos de semillas estuvieron pobremente correlacionadas con las características de la comunidad vegetal. La calificación de la condición de los pastizales estuvo positivamente correlacionado $(r=0.17, P=0.09)$ con las densidades totales de plántulas en el banco de semillas del suelo, indicando que más plántulas pueden potencialmente desarrollarse de un banco de semillas de las comunidades vegetales con una condición ascendente del pastizal. Rechazamos la hipótesis de que el "Clubmoss" afecte negativamente la composición de los bancos de semillas. Se predijo que el disturbio mecánico de las comunidades de plantas para controlar el "Clubmoss" lleva a comunidades que son dominadas especies de plantas crecientes y/o invasoras. El manejo para la producción de semilla de especies deseables debe ser una prioridad para promover el establecimiento de especies deseables. 
Dyne and Vogel 1967, Dolan and Taylor 1972). This spore-reproducing perennial, generally increases with grazing or drought (Clarke et al. 1943, Heady 1952, Campbell et al. 1962, Smoliak 1965, Smoliak et al. 1972), but it also can decrease with intense grazing and trampling (Coupland 1950, Van Dyne and Vogel 1967). Extensive ground cover of clubmoss in the Northern Mixed Prairie has led some people to assume that this plant alters composition of plant communities (Ryerson et al. 1970, Dolan and Taylor 1972).

Clubmoss is an important aspect of seedbed ecology in the Northern Great Plains because it occupies a large amount of the soil surface (Bai and Romo 1995). Heady (1952) concluded that clubmoss limits establishment of grasses, but Smoliak et al. (1976) believed that seedling establishment is not affected by clubmoss in years of abundant precipitation. Mosses can reduce or have no effect on seedling emergence and survival (Rabotnov 1969). Substantial numbers of seeds are generally present in soil on rangeland (Archibold 1981, Grilz and Romo 1995), and the total number of seeds and the proportion of early successional species in the soil seed bank can increase with grazing pressure (Johnston et al. 1969, Willms and Quinton 1995). Species composition of soil seed banks and plant communities can be similar (Johnson and Anderson 1986, Henderson et al. 1988), dissimilar (Coffin and Lauenroth 1989, Peco et al. 1998, Lunt 1990, Lopez-Marino et al. 2000, Tracy and Sanderson 2000) and can vary with grazing pressure (Dutoit and Alard 1995) and successional stages (Tracy and Sanderson 2000).

In Saskatchewan many range managers have suggested that clubmoss inhibits establishment of desirable species, primarily species that decrease under improper grazing management. This prediction presumes that seeds of decreaser species are present in the seed bank and removal of clubmoss will allow decreasers to establish from seeds. Alternatively, composition of seed banks may be unrelated to clubmoss and few seeds of decreasers may be present in seed banks. The purpose of this study was to determine the composition and diversity of the soil seed bank in relation to the cover of clubmoss and compositional characteristics of grazed plant communities in the Northern Mixed Prairie in southwestern Saskatchewan.

\section{Methods}

This study was conducted in the Mixedgrass Ecoregion in the Prairie Ecozone (Padbury and Acton 1994) of southwestern Saskatchewan $\left(49-51^{\circ} \mathrm{N}\right.$, $\left.106-110^{\circ} \mathrm{W}\right)$. This region was selected because it has the most native grassland remaining in Saskatchewan, and it is in this area that many range managers perceive clubmoss as a management issue. Soils of the study area are primarily Brown Chernozems (Ayres et al. 1985) derived from glacial and postglacial deposits (Christiansen 1979) and they range in texture from clay to sandy (Coupland 1950, 1961). Temperatures of the area vary from a mean of about $-17^{\circ} \mathrm{C}$ in January to $19^{\circ} \mathrm{C}$ in July, and average about $3^{\circ} \mathrm{C}$ annually (Environment Canada 1982). Annual precipitation averages about 300 to $400 \mathrm{~mm}$ of which most is received in May through July (Environment Canada 1982). Plant communities in the Mixedgrass Ecoregion are typical of the Northern Mixed Prairie Association (Stipa-Bouteloua) (Coupland $1950,1961,1992)$ and are characterized by perennial plants including needle-andthread (Stipa comata Trin. \& Rupr.), western porcupine grass (Stipa spartea var. curtiseta Hitchc.), western wheatgrass (Agropyron smithii Rydb.), northern wheatgrass (Agropyron dasytachyum [Hook.] Scribn.), Junegrass (Koeleria cristata Pers.), blue grama (Bouteloua gracilis [HBK.] Lag.), sedge (Carex stenophylla Wahl. ssp. eleocharis [Bailey] Hulten), and fringed sagebrush (Artemisia frigida [Willd.]). Annual plants are uncommon in these grasslands (Coupland 1950, 1961, 1992) except on disturbed sites.

One hundred pastures supporting native plant communities were randomly selected to provide a variety of managerial activities, range sites, range condition and clubmoss cover. Land that had been cultivated or was seeded to tame forages was not sampled. Sampling was completed in September because seed reserves in the soil were expected to be greatest at this time of the year. After a site was selected, the soil taxonomic unit was determined from soil surveys completed by the Saskatchewan Soil Survey (Ayres et al. 1985), and the range site was determined (Abouguendia 1990). Of the 100 range sites sampled, 7 were classified as clayey, 64 were loamy, 3 were sands, 7 were sandy, and 17 were thin and 2 were badland. At each site, $2,0.5$ by $0.5 \mathrm{~m}$ quadrats were randomly established $5 \mathrm{~m}$ apart, and percent canopy cover of each plant species in each quadrat was visually estimated to the nearest $5 \%$. Cover for each species from the 2 quadrats was averaged and range condition was estimated (Abouguendia 1990). Taxonomy of plants follows Budd (1987).

Across all sites sampled, clubmoss cover was between 3 and $63 \%(\bar{x}=23$, SE $\pm 1.3)$ and range condition scores varied between 10 and $61(\bar{x}=32, S E \pm 1.0)$. Four percent of the plant communities were in good range condition, $69 \%$ were in fair range condition, and $27 \%$ were in poor range condition. Canopy cover ranged from 0 to $75 \%(\overline{\mathrm{x}}=14, \mathrm{SE} \pm 1.4)$ for decreasers, 5 to $81 \%(\overline{\mathrm{x}}=50, \mathrm{SE} \pm 1.6)$ for increasers, and 0 to $20 \%(\bar{x}=2.0, S E \pm$ 0.4 ) for invaders. Needle-and-thread, northern wheatgrass and western wheatgrass were the most important decreasers in the plant communities while blue grama, Junegrass, fringed sagebrush, sedges (Carex spp.) and native bluegrass (Poa secunda Presl.) were the most important increasers (Table 1). Invaders were uncommon in plant communities. Cover of clubmoss was negatively correlated with cover of decreasers $(Y=20.0-0.21 X$, $r^{2}=0.04, P=0.05$ where $Y$ is cover of decreasers and $\mathrm{X}$ is cover of clubmoss) and with cover of increasers $(Y=59.0$ $0.40 \mathrm{X}, \mathrm{r}^{2}=0.11, \mathrm{P}<0.01$ where $\mathrm{Y}$ is cover of increasers and $\mathrm{X}$ is cover of clubmoss). Cover of invaders was poorly correlated with cover of clubmoss $(P=0.39)$. Species richness and the Shannon-Weiner diversity index for plant communities varied between 3 and 15 species per $0.5 \mathrm{~m}^{2}(\overline{\mathrm{x}}$ $=6.4, \mathrm{SE} \pm 0.2)$ and 0.48 to $2.58(\overline{\mathrm{x}}=$ $1.57, \mathrm{SE} \pm 0.04)$, respectively.

One soil core that was $5.7 \mathrm{~cm}$ in diameter and $7.5 \mathrm{~cm}$ long (volume of soil $=91$ $\mathrm{cm}^{3}$, area $=25.5 \mathrm{~cm}^{2}$ ) was collected from 2 random locations in each quadrat where plant community cover was determined. The soil cores from the 2 quadrats were combined in a plastic bag (volume of soil $=765 \mathrm{~cm}^{3}$, area $=102 \mathrm{~cm}^{2}$ ) and air-dried in the laboratory for about 3 months. We combined seed bank samples at each site because of our interest in relationships among continuously distributed characteristics of the seed bank and plant communities. Furthermore variation among soil seed banks at a particular site was not of interest and pastures could not be replicated. Soil samples for each site were mixed thoroughly and placed in a 12.5 by 25 by 5 $\mathrm{cm}$ tray. Soil samples were about 2 to 3 $\mathrm{cm}$ in thickness in the trays. The soil samples were watered and randomly placed in a growth chamber with 12 hours of darkness at $8^{\circ} \mathrm{C}$ and 12 hours light $(220 \mu \mathrm{mol}$ 
Table 1. Relative importance $(\%)$ of decreaser, increaser and invader species present in soil seed banks and the relative importance of these same species in the plant communities in 94 grazed pastures in southwestern Saskatchewan. Taxonomy is based on Budd (1987) while classification as decreasers, increasers, and invaders follows Abouguendia (1990).

\begin{tabular}{|c|c|c|c|}
\hline Common name & Latin name & $\begin{array}{c}\text { Plant } \\
\text { communities } \\
--(\%)---\end{array}$ & $\begin{array}{c}\text { Seed } \\
\text { bank } \\
--(\%)-\cdots\end{array}$ \\
\hline & \multicolumn{3}{|c|}{ - } \\
\hline needle-and-thread & Stipa comata Trin.\&Rupr. & 69 & 2 \\
\hline green needlegrass & Stipa viridula Trin. & $<1$ & $<1$ \\
\hline western wheatgrass & Agropyron smithii Rydb. & 5 & $<1$ \\
\hline indian ricegrass & Oryzopsis hymenoides (Roem.\&Schult.) Ricker & 0 & $<1$ \\
\hline northern wheatgrass & Agropyron dasystachyum (Hook.) Scribn. & 10 & $<1$ \\
\hline western porcupine grass & Stipa spartea var. curtiseta Hitchc. & $\mathbf{0}$ & $<1$ \\
\hline sand dropseed & Sporobolus cryptandrus (Torr.) A. Gray & 0 & $<1$ \\
\hline slender wheatgrass & Agropyron trachycaulum (Link) Malte & 0 & $<1$ \\
\hline Junegrass & Koeleria cristata Pers. & 87 & 100 \\
\hline fringed sagebrush & Artemisia frigida Willd. & 73 & 25 \\
\hline sedge & Carex sp. & 64 & 18 \\
\hline native bluegrass & Poa secunda Presl. & 8 & 2 \\
\hline blue grama & Bouteloua gracilis (HBK.) Lag. & 100 & $<1$ \\
\hline yellow umbrellaplant & Eriogonum flavum Nutt. & 0 & $<1$ \\
\hline coneflower & Ratibida columnifera (Nutt.) Woot.\&Stanl. & $<1$ & $<1$ \\
\hline spiny ironweed & Haplopappus spinulosus (Pursh) DC. & 0 & $<1$ \\
\hline hairy goldenaster & Chrysopsis villosa (Pursh) Nutt. & $<1$ & $<1$ \\
\hline prairie cinquefoil & Potentilla pensylvanica $\mathrm{L}$. & 0 & $<1$ \\
\hline silverleaf psoralea & Psoralea argophylla Pursh & $<1$ & $<1$ \\
\hline Missouri milkvetch & Astragalus missouriensis Nutt. & 0 & $<1$ \\
\hline narrow-leaved milkvetch & Astragalus pectinatus Dougl. & 0 & $<1$ \\
\hline sand bladderpod & Lesquerella ludoviciana (Nutt.) Wats. & 0 & $<1$ \\
\hline beardtongue & Penstemon sp. & 0 & $<1$ \\
\hline goldenrod & Solidago sp. & $<1$ & $<1$ \\
\hline pygmyflower & Androsace septentrionalis $\mathrm{L}$. & $<1$ & 33 \\
\hline flixweed & Descurainia sophia (L.) Webb. & 0 & 2 \\
\hline bluebur & Lappula echinata Gilib. & $<1$ & $<1$ \\
\hline monolepis & Monolepis nuttalliana (R.\&S.) Grene & 0 & $<1$ \\
\hline Kentucky bluegrass & Poa pratensis L. & $<1$ & $<1$ \\
\hline red-root pigweed & Amaranthus retroflexus $\mathrm{L}$. & 0 & $<1$ \\
\hline wild barley & Hordeum jubatum L. & 0 & $<1$ \\
\hline wild buckwheat & Polygonum convolvulus L. & 0 & $<1$ \\
\hline dandelion & Taraxacum officinale Weber & 0 & $<1$ \\
\hline wild tomato & Solanum triflorum Nutt. & 0 & $<1$ \\
\hline yellow sweetclover & Melilotus officinalis (L.) Pall. & 0 & $<1$ \\
\hline biennial wormwood & Artemisia biennis Willd. & 0 & $<1$ \\
\hline lamb's quarter & Chenopodium album $\mathrm{L}$. & 0 & $<1$ \\
\hline thistle & Cirsium sp. & 0 & $<1$ \\
\hline narrow-leaved hawk's beard & Crepis tectorum $\mathrm{L}$ & 0 & $<1$ \\
\hline thyme-leaved spurge & Euphorbia serpyllifolia Pers. & 0 & $<1$ \\
\hline western marsh cudweed & Gnaphalium palustre Nutt. & 0 & $<1$ \\
\hline yellow goat's beard & Tragopogon dubius Scop. & 0 & $<1$ \\
\hline Unknown forbs (4) & & 0 & $<1$ \\
\hline
\end{tabular}

$\left.\mathrm{m}^{-2} \mathrm{sec}^{-1}\right)$ at $20^{\circ} \mathrm{C}$. These temperatures were selected to correspond with field temperatures in the spring, the time when most seedlings emerge in these grasslands (Bai and Romo 1996, Romo and Grilz 2002). Soil samples were randomly rearranged in the growth chamber at about 1-week intervals throughout the experiment and kept moist by watering every 1 to 3 days. Emerging seedlings were identified to species and removed every 10 to 14 days. Seedling emergence was nearly nil after about 30 days, but the soil samples were stirred and incubated 60 more days

\section{Data analysis}

No seedlings emerged from 6 of the 100 soil seed bank samples, thus they were not included in statistical analyses. Species richness and the Shannon diversity index were determined for seedlings emerging from each seed bank sample (Barbour et al. 1999). Jaccards' similarity index of species composition in the plant community and the soil seed bank was calculated for each site using the number of common species divided by the total number of species in both the plant community and soil seed bank (Barbour et al. 1999). This similarity index ranges from 0 , or no similarity, to 1 or identical composition. Relative importance for each species was determined in the plant communities and the seed banks by multiplying constancy of each species among plant communities or seed banks by the proportion of the total cover in plant communities or the total number of seedlings emerging from each seed bank. Regression analysis was used to test correlations between cover of clubmoss, range condition score, species richness and diversity, and cover of decreasers, increasers and invaders in plant communities with seed bank characteristics including species richness and diversity, density of decreaser, increaser and invader seedlings and total seedling densities (Snedecor and Cochran 1980). Statistical significance was $P \leq 0.10$ in all cases.

\section{Results and Discussion}

\section{Seed bank characteristics}

Seedlings of 46 species emerged from the seed banks of which 14 species were perennial graminoids and 32 species were forbs (Table 2). Perennial grasses were also poorly represented in soil seed banks elsewhere in the Northern Mixed Prairie (Hild et al. 2001). Increasers and invaders were the most important groups in the seed banks. Decreaser species constituted $8 \%(\mathrm{SE} \pm 1.9)\left(0.5\right.$ seedlings per $102 \mathrm{~cm}^{2}$, $\mathrm{SE}=0.12$ ) of all seedlings emerging with needle-and-thread being most important decreaser (Table 1). Seventy-three percent $(\mathrm{SE} \pm 2.8)$ of the emerging seedlings were increasers (5.6 seedlings per $102 \mathrm{~cm}^{2}, \mathrm{SE}$ \pm 0.50 ); Junegrass was the most important increaser followed by fringed sagebrush, sedges, and native bluegrass. Junegrass and bluegrasses (Poa sp. [species not specified]) were also the most common perennial grasses in seed banks from grazed foothills prairie in Alberta (Lagroix-McLean and King 1989). 
Table 2. Correlations between the compositional characteristics of plant communities and soil seed banks on 94 grazed pastures in southwestern Saskatchewan. Significant correlation coefficients $(\mathrm{P} \leq \mathbf{0 . 1 0})$ are bold and underlined.

\begin{tabular}{lcccccr}
\hline \hline & \multicolumn{5}{c}{ Seedbank characteristic } \\
\cline { 2 - 7 } $\begin{array}{l}\text { Plant } \\
\text { community } \\
\text { characteristic }\end{array}$ & $\begin{array}{c}\text { Species } \\
\text { richness }\end{array}$ & $\begin{array}{c}\text { Species } \\
\text { diversity }\end{array}$ & $\begin{array}{c}\text { Decreaser } \\
\text { density }\end{array}$ & $\begin{array}{c}\text { Increaser } \\
\text { density }\end{array}$ & $\begin{array}{c}\text { Invader } \\
\text { density }\end{array}$ & $\begin{array}{r}\text { Total } \\
\text { seedling } \\
\text { density }\end{array}$ \\
\hline Clubmoss cover & -0.03 & 0.06 & -0.01 & 0.01 & -0.09 & $<0.01$ \\
Range condition score & -0.04 & 0.05 & 0.11 & -0.15 & -0.11 & $\underline{\mathbf{0 . 1 7}}$ \\
Species richness & 0.06 & 0.05 & 0.11 & 0.06 & 0.04 & 0.06 \\
Species diversity & 0.08 & 0.06 & 0.08 & 0.10 & 0.09 & 0.10 \\
Decreaser cover & -0.15 & -0.08 & $<0.01$ & $\underline{\mathbf{0 . 2 0}}$ & -0.08 & $\underline{\mathbf{0 . 2 2}}$ \\
Increaser cover & 0.13 & 0.08 & 0.09 & 0.13 & $\underline{\mathbf{0 . 2 3}}$ & $\underline{\mathbf{0 . 2 3}}$ \\
Invader cover & -0.03 & 0.16 & -0.07 & $\underline{\mathbf{0 . 3 0}}$ & -0.06 & $\underline{\mathbf{0 . 2 1}}$ \\
\hline
\end{tabular}

Among emergent seedlings, $19 \%$ (SE \pm 2.3) were invaders ( 1.7 seedlings per 102 $\mathrm{cm}^{2}, \mathrm{SE} \pm 0.30$ ). Pygmyflower (Androsace septentrionalis L.), a native annual, was the most important invader while flixweed (Descurainia sophia [L.] Webb.), a nonnative annual, was second in importance. Pygmyflower and fringed sagebrush were the most common native forbs in the seed banks, similar to reports from other grasslands in Saskatchewan and Alberta (Lagroix-McLean and King 1989, Grilz and Romo 1995 , Willms and Quinton 1995).

\section{Relationships between composition of seed banks and plant communities}

The seed banks and plant communities shared few species as indicated by the low similarity index $(\overline{\mathrm{x}}=0.31, \mathrm{SE} \pm 0.02$, range 0.00 to 0.60 ). Johnston et al. (1969), Lunt (1990), Kinucan and Smeins (1992), Bekker et al. (1997), Peco et al. (1998), Perez et al. (1998), Lopez-Marino et al. (2000) and Tracy and Sanderson (2000) also reported little similarity between botanical composition of seedlings emerging from seed banks and established plant communities. Lack of similarity between seed banks and plant communities may be attributed to inputs of seeds from plant communities that have changed through time and inputs from different communities in space. Predation, differential rates of loss of seed viability, and movement of seeds from the sites may also reduce similarity of seed banks and plant communities. In other studies (Johnson and Anderson 1986, Henderson et al. 1988) the abundance of species in the seed bank was positively correlated with aboveground vegetation. Grazing management (Dutoit and Alard 1995, Bekker et al. (1997), soil texture (Coffin and Lauenroth (1989), and successional status of plant communities (Tracy and Sanderson 2000) all contribute to similarity of vegetation and soil seed banks. seed bank composition agrees with Perez et al. (1998) and contrasts with differences in seed bank species composition under different grazing intensities (Kinucan and Smeins 1992, Willms and Quinton 1995) in which early seral species tended to increase with grazing while late seral species decreased.

Total seedling densities averaged 7.8 per $102 \mathrm{~cm}^{2}(\mathrm{SE} \pm 0.62)$. These seedling densities are within the range for soil seed banks in Mixed Prairie (Johnston et al. 1969) and Fescue Prairie in Alberta and Saskatchewan (Archibold 1981, Willms and Quinton 1985, Grilz and Romo 1995). Total seedling density increased with range condition score $(P=0.09)$, cover of increasers $(P=0.03)$ and invaders $(P<$ 0.01 ) in plant communities. Increased seed densities with increasing grazing intensity were reported by Russi et al. (1992), Willms and Quinton (1995) and Marco and Paez (2000). The total density of seedlings emerging from the seed banks was negatively correlated $(P=0.03)$ with cover of decreasers in plant communities.

In summary, the fact that decreaser species were a minor component of seed banks suggest that low seed numbers likely limit the potential for regeneration of decreaser species from seed banks. On the other hand, increaser and invader species were most the most important species groups in seed banks and their regeneration from seed may not be seed limited. Since invader and increaser species dominated the seed banks, mechanically disturbing plant communities to control clubmoss is predicted to lead to plant communities that are dominated by increasers and/or invaders as described by Ryerson et al. (1970). It remains to be determined whether clubmoss, other biotic factors, or factors of the physical environment place greater limitations on emergence and establishment of decreasers when seed numbers are not limited. Seed production can vary substantially from year-to-year and relationships among compositional characteristics of plant communities and seedbanks might therefore vary accordingly. Although the economic feasibility of mechanically disturbing range to reduce clubmoss is questionable (Kulshreshtha et al. 2002) it may be useful to manage for production of seeds by desired species or species groups and then, if necessary, to time control treatments with production of abundant amounts of viable seeds. 


\section{Literature Cited}

Abouguendia, Z.M. 1990. A practical guide to planning for management and improvement of Saskatchewan rangeland: Range plan development. New Pasture and Grazing Technologies Project. Regina, Sask.

Archibold, O.W. 1981. Buried viable propagules in native prairie and adjacent agricultural sites in central Saskatchewan. Can. J. Bot. 59:701-706.

Ayres, K.W., D.F. Acton, and J.G. Ellis. 1985. The soils of the Swift Current Map Area 72J Saskatchewan. Ext. Division, Univ. Saskatchewan, Saskatoon, Sask.

Bai, Y. and J.T. Romo. 1995. Seedling emergence of Artemisia frigida in relation to hydration-dehydration cycles and seedbed characteristics. J. Arid Environ. 30:57-65.

Bai, Y. and J.T. Romo. 1996. Fringed sagebrush response to sward disturbances: Seedling dynamics and plant growth. J. Range Manage. 49:228-233.

Barbour, M.G., J.H. Burk, W.D. Pitts, F.S. Gilliam, and M.W. Schwartz. 1999. Terrestrial plant ecology. $3^{\text {rd }}$ ed. Benjamin/Cummings. Menlo Park, Calif.

Bekker, R.M., G.L. Verweij, R.E.N. Smith, R. Reine, J.P. Bakker, and S. Schneider. 1997. Soil seed banks in European grasslands: Does land use affect regeneration perspectives? J. Appl. Ecol. 34:1293-1310.

Budd, A.C. 1987. Budd's flora of the Canadian Prairie Provinces. Canadian Gov. Publ. Centre, Hull, Quebec.

Campbell, J.B., R.W. Lodge, A. Johnston, and S. Smoliak. 1962. Range management of grasslands and adjacent parklands in the Prairie Provinces. Canada Dept. Agr. Publ. 1133. Ottawa, Ont.

Christiansen, E.A. 1979. The Wisconsinan deglaciation of southern Saskatchewan and adjacent areas. Can. J. Earth Sci. 16:913-938.

Clarke, S.E., E.W. Tisdale, and N.A. Skoglund. 1943. The effects of climate and grazing practices on shortgrass prairie vegetation in southern Alberta and southwestern Saskatchewan. Canada Dept. Agr. Tech. Bull. 46. Ottawa, Ont.

Coffin, D.P. and W.K. Lauenroth. 1989. Spatial and temporal variation in the seed bank of a semiarid grassland. Amer. J. Bot. 76:53-58.

Coupland, R.T. 1950. Ecology of mixed prairie in Canada. Ecol. Monogr. 20:271-315.

Coupland, R.T. 1961. A reconsideration of grassland classification in the Northern Great Plains. J. Ecol. 49:135-167.

Coupland, R.T. 1992. Mixed prairie. p. 151182. In: R.T. Coupland (ed.) Natural grasslands: Introduction and western hemisphere. Ecosystems of the world 8a. Elsevier, New York, N.Y.

Dolan, J.J. and J.E. Taylor. 1972. Residual effects of range renovation on dense clubmoss and associated vegetation. J. Range Manage. 25:32-37.
Dutoit, T. and D. Alard. 1995. Permanent seed banks in chalk grassland under various management regimes: Their role in the restoration of species-rich plant communities. Biodiversity Conserv. 4:939-950.

Environment Canada, Atmospheric Environmental Service. 1982. Canada climate normals (1951-1980), temperature and precipitation (Prairie Provinces). Environ. Canada. Ottawa, Ont.

Grilz, P.L. and J.T. Romo. 1995. Management considerations for controlling smooth brome in Fescue Prairie. Natur. Areas J. 15:148-156.

Heady, H.F. 1952. Reseeding, fertilizing, and renovating in an ungrazed mixed prairie. J. Range Manage. 5:144-149.

Henderson, C.B., K.E. Peterson, and R.A. Redak. 1988. Spatial and temporal patterns in the seed bank and vegetation of a desert grassland community. J. Ecol. 76:717-728.

Hild, A.L., M.G. Karl, M.R. Haferkamp, and R.K. Heitschmidt. 2001. Drought and grazing III: Root dynamics and germinable seed bank. J. Range Manage. 54:292-298.

Johnson, R.G. and R.C. Anderson. 1986. The seed bank of a tallgrass prairie in Illinois. Amer. Midl. Nat. 115:123-130.

Johnston, A., S. Smoliak, and P.W. Stringer. 1969. Viable seed populations in Alberta prairie topsoils. Can. J. Plant Sci. 49:75-82.

Kinucan, R.J. and F.E. Smeins. 1992. Soil seed bank of a semiarid Texas grassland under three long-term (36-years) grazing regimes. Amer. Midl. Nat. 128:11-21.

Kulshreshtha, S.N., J.T. Romo, and Peng Hongjia. 2002. Economic analysis of mechanically disturbing rangeland to reduce clubmoss in Saskatchewan. Can. J. Plant Sci. 82:739-746.

Lagroix-McLean, R. and J.R. King. 1989. Buried viable seeds in the Alberta foothills under high intensity low frequency grazing and the resemblance to seed rain. p. 1067-1068. In: Proc. XVI International Grassland Congress. Eastview Press, Boulder, Colo.

Lopez-Marino, A., E. Luis-Calabuig, F. Fillat, and F.F. Bermudez. 2000. Floristic composition of established vegetation and the soil seed bank in pasture communities under different traditional management regimes. Agr. Ecosys. Environ. 78:273-282.

Lunt, I.D. 1990. The soil seed bank of a longgrazed Themeda triandra grassland in Victoria. Proc. Royal Soc. Victoria 102:53-57.

Marco, D.E. and S.A. Paez. 2000. Soil seed banks on Argentine semi-natural mountain grasslands after cessation of grazing. Mount. Res. Develop. 20:254-261.

Padbury, G.A. and D.F. Acton. 1994. Ecoregions of Saskatchewan. Minister of Supply and Services, Ottawa, Ont.

Peco, B., M. Ortega, and C. Levassor. 1998. Similarity between seed bank and vegetation in Mediterranean grassland: A predictive model. J. Veg. Sci. 9:815-828.
Perez, C.J., S.S. Waller, L.E. Moser, J.L. Stubbendieck, and A.A. Steuter. 1998. Seed bank characteristics of a Nebraska sandhills prairie. J., Range Manage. 51:55-62.

Rabotnov, T.A. 1969. Plant regeneration from seed in meadows of the USSR. Herb. Abstr. 39:269-277.

Romo, J.T. and R.W. Grilz. 2002 . Establishment of silver sagebrush in the Northern Mixed Prairie. J. Range Manage. 55:217-221.

Russi, L., P.S. Cocks, and E.H. Roberts. 1992. Seed bank dynamics in a Mediterranean grassland. J. Appl. Ecol. 29:763-771.

Ryerson, D.E., J.E. Taylor, L.O. Baker, H.A.R. Houlton, and D.W. Stroud. 1970. Clubmoss on Montana rangelands: Distribution-control-range relationships. Montana Agr. Exp. Sta. Bull. 645. Montana State Univ. Bozeman, Mont.

Smoliak, S. 1965. A comparison of ungrazed and lightly grazed Stipa-Bouteloua prairie in southeastern Alberta. Can. J. Plant Sci. 45:270-275.

Smoliak, S., J.F. Dormaar, and A. Johnston. 1972. Long-term grazing effects on StipaBouteloua prairie soils. J. Range Manage. 25:246-250.

Smoliak, S., A. Johnston, M.R. Kilcher, and R.W. Lodge. 1976. Management of prairie rangeland. Canada Dept. Agr. Publ. 1589. Ottawa, Ont.

Snedecor, G.W. and W.G. Cochran. 1980. Statistical methods. Iowa State Univ. Press. Ames, lowa.

Taylor, J.E. 1967. Range pitting and nitrogen fertilization on mixed prairie rangeland in northern Montana. M.S. Thesis, Montana. State Univ., Bozeman, Mont.

Tracy, B.F. and M.A. Sanderson. 2000. Seed bank diversity in grazing lands of the Northeast United States. J. Range Manage. 53:114-118.

Van Dyne, G.M. and W.G. Vogel. 1967. Relation of Selaginella densa to site, grazing, and climate. Ecology 48:438-444.

Willms, W.D. and D.A. Quinton. 1995. Grazing effects on germinable seeds in fescue prairie. J. Range Manage. 48:423-430. 